\title{
KESEDARAN KEUSAHAWANAN DALAM KALANGAN PELAJAR INSTITUT LATIHAN PERINDUSTRIAN (ILP) JABATAN TENAGA MANUSIA DI TERENGGANU
}

\author{
WAN NAQIYAH WAN ABDUL MAJID AND ROHANA AHMAD* \\ Faculty of Business, Economics and Social Development, Universiti Malaysia Terengganu, 21030 Kuala Nerus, \\ Terengganu
}

*Corresponding author: rohana.a@umt.edu.my

http://doi.org/10.46754/umtjur.2021.01.010

\begin{abstract}
Abstrak: Keusahawanan sering dianggap sebagai subjek yang lebih cenderung kepada pelajar dalam bidang perniagaan tetapi tidak untuk pelajar yang mempunyai pelbagai kemahiran yang terlibat dalam bidang teknikal. Namun, ini adalah satu tanggapan yang tidak seharusnya wujud kerana Malaysia seharusnya perlu mengenal pasti kesedaran keusahawanan dalam bidang teknikal. Pada masa kini, kesedaran keusahawanan dalam bidang teknikal tertentu adalah kurang lantaran program keusahawanan lazimnya lebih tertumpu kepada pelajar InstitusiPengajian Tinggi (IPT). Misalnya, Pembangunan Keusahawanan Bumiputera adalah lebih tertumpu kepada golongan siswazah IPT, belia dan wanita. Dasar Pembangunan Keusahawanan IPT juga diperkenalkan agar modal insan dengan daya pemikiran, atribut dan nilai keusahawanan dalam kalangan IPT tempatan dapat dilahirkan. Tujuan kajian ini dijalankan adalah untuk mengenal pasti tahap kesedaran keusahawanan dalam kalangan pelajar Institut Latihan Perindustrian (ILP) di Terengganu berhubung dengan faktor keusahawanan dari aspek individu usahawan yang berbeza serta struktur dan persekitaran perniagaan. Seterusnya, mengkaji hubungan antara kesedaran keusahawanan dengan pembolehubah tidak bersandar lain yang berkait dengan kajian seperti ciri keusahawanan dan cabaran keusahawanan. Kaedah kuantitatif telah digunakan dan borang soal selidik diedarkan kepada 280 orang pelajar. Hasil analisis regresi berganda menunjukkan bahawa cabaran keusahawanan merangkumi sikap dan minat, kemahiran keusahawanan serta pendidikan dan pengetahuan keusahawanan merupakan elemen paling signifikan yang mempengaruhi kesedaran keusahawanan dalam kalangan pelajar berkemahiran di ILP untuk menjadi seorang usahawan. Oleh itu, adalah sangat penting bagi kerajaan Malaysia untuk memberi perhatian terhadap cabaran yang dihadapi oleh para pelajar ini dan mengambil tindakan terhadap segala kemungkinan yang boleh mempengaruhi atau memberi kesan kepada minat pelajar terhadap keusahawanan pada masa akan datang.
\end{abstract}

Kata kunci: Kesedaran Keusahawanan, Jabatan Tenaga Manusia, Aspek Individu, Struktur dan Persekitaran Perniagaan, Ciri dan Cabaran.

\section{ENTREPRENEURSHIP AWARENESS AMONGST THE STUDENTS OF INDUSTRIAL TRAINING INSTITUTE (ILP) MANPOWER DEPARTMENT IN TERENGGANU}

\begin{abstract}
Entrepreneurship is often considered as a subject more likely to students in the business discipline compared to skilled students in technical field. However, this notion should not exist as Malaysia should recognize the importance of entrepreneurship awareness. Currently, entrepreneurship awareness is lacking in certain technical courses as entrepreneurship programs usually focused more on the higher educational students. For example, Bumiputera Entrepreneurship Development concentrated more on the students of Higher Education Institutions (HEIs), youth and women. Even the HEIs Entrepreneurship Development Policy was also introduced to produce humankind with entrepreneurial mindset, attributes and values. The purpose of this paper is to identify the
\end{abstract}


level of entrepreneurship awareness amongst the students of Industrial Training Institute (ILP) in Terengganu in regards to relevance factors such as different individual aspects of entrepreneurs as well as the structure and business environment. This paper also tries to investigate the relationship between entrepreneurship awareness with other related independent variables. Such variables are entrepreneurship features and entrepreneurship challenges. The quantitative method was used, and questionnaires had been distributed to 280 students. The result of multiple regression demonstrated that entrepreneurship challenges comprises of attitude and interest, entrepreneurial skills as well as education and entrepreneurial knowledge was the most significant predictor of entrepreneurship awareness amongst the skilled students in the industrial training institute (ILP) to be an entrepreneur. It is crucial for Malaysian government to realize the challenges that these students are facing. Malaysian government must take a swift action against all odds that might affect the students' interest towards entrepreneurship in the future.

Keywords: Entrepreneurship Awareness, Manpower Department, Individual Aspects, Structure and Business Environment, Features and Challenges.

\section{Pengenalan}

Sehingga kini, pelbagai dasar kerajaan sedia ada yang telah digubal sejak tahun 90 -an amat menitikberatkan kepentingan bidang keusahawanan. Bidang keusahawanan merupakan satu bidang yang strategik dalam sektor ekonomi. Menerusi RMK-10, Malaysia jelas ingin maju sebagai sebuah negara berpendapatan tinggi pada tahun 2020 melalui penekanan terhadap intipati dalam rancangan tersebut. Misalnya, melalui Pengukuhan Keupayaan dan Pembudayaan Keusahawanan yang mana aspek tersebut merupakan salah satu bidang keberhasilan utama dalam RMK-10 yang ditetapkan oleh kerajaan. Malah, mantan Menteri Pendidikan Tinggi Malaysia, Dato'Seri Idris Jusoh, turut menyatakan bahawa di bawah Rancangan Malaysia Ke-11 (RMK-11), aktiviti keusahawanan adalah sangat signifikan dalam usaha membangunkan modal insan. Modal insan ini bertindak untuk menyokong peralihan sektor-sektor ekonomi kepada aktiviti berintensif pengetahuan dan inovasi.

Secara ringkas, keusahawanan boleh didefinisikan sebagai proses penciptaan sesebuah organisasi (Gartner \& Bellamy, 2009). Hal ini adalah bersesuaian dengan kajian yang dijalankan oleh Kuratko dan Hodgets (2011) yang menerangkan keusahawanan sebagai satu perkara baharu yang tercipta melalui empat dimensi utama iaitu individu, organisasi, proses dan persekitaran. Manakala, usahawan boleh didefinisikan sebagai golongan individu atau kumpulan yang terlibat dengan aktiviti perniagaan yang dibangunkan dan diusahakan sendiri (Audia \& Rider, 2005) dan hal ini turut dipersetujui oleh Hisrich et al (2008). Beliau melihat usahawan sebagai seseorang individu yang sedia berkorban daripada segi peruntukan masa, daya tumpuan dan keupayaan tenaga yang tinggi. Komitmen ini penting bagi menjalankan aktiviti keusahawanan, menanggung risiko kewangan, psikik dan sosial dalam usaha serta proses penghasilan produk yang baru dan bernilai, seterusnya memperoleh ganjaran daripada usaha-usaha tersebut. Misalnya, ganjaran dalam bentuk kewangan serta kepuasan dan kebebasan (Hisrich et. al 2008).

Chiew et. al (2011) berpendapat usahawan ialah seseorang yang berinisiatif yang membawa pembaharuan dalam kaedah mengumpulkan keperluan pelbagai sumber. Mereka juga mampu bertindak dalam keadaan ketidakpastian. Selain memberi manfaat yang besar kepada individu, hal ini juga akan menyumbang kepada pembangunan ekonomi negara melalui pendapatan yang diperoleh dalam bidang keusahawanan dan turut menyumbang 
kepada pembangunan yang melibatkan struktur perniagaan dan masyarakat (Idris, 2009).

Malaysiasepertikebanyakannegaralain juga menghadapi masalah pengganguran. Oleh yang demikian, kerajaan amat menggalakkan pelajar lepasan ijazah untuk menceburi bidang keusahawanan. Ia berikutan dengan kesukaran mereka untuk memperoleh pekerjaan selepas graduasi. Pada tahun 2015, pengangguran belia mencecah $10.7 \%$ dan jumlah ini adalah tiga kali lebih tinggi daripada kadar pengangguran negara sebanyak 3.1\% (Laporan Tahunan Bank Negara Malaysia, 2016). Sehingga Ogos 2017, melalui Sistem Kajian Pengesanan Graduan (SKPG), kerajaan di bawah Kementerian Pendidikan Tinggi (KPT) mendapati seramai 54,103 graduan IPT masih menganggur walaupun selepas tempoh enam bulan menamatkan pengajian (Utusan Online, Ogos 2017).

Lantaran itu, transformasi dalam sistem penyampaian oleh IPT perlulah dilakukan secara proaktif. Keperluan transformasi dalam sistem penyampaian ilmu oleh IPT ini adalah supaya ia lebih bersifat fleksibel dan entrepreneurial selain menepati kehendak dalam negara (local) dan dalam masa yang sama turut bersifat global. Perubahan ini dilakukan supaya insan yang holistik, seimbang daripada segi sahsiah dan akademik serta mempunyai minda keusahawanan dapat dilahirkan melalui sistem pendidikan tinggi dan seterusnya menjadi penjana pekerjaan (job creator) seperti yang dihasratkan di bawah Lonjakan 1, Pelan Pembangunan Pendidikan Malaysia 2015-2025 (Pendidikan Tinggi) atau PPPM (PT) (Kementerian Pendidikan Tinggi, 2016).

Oleh yang demikian kajian ini membincangkan tiga persoalan penting mengenaikeusahawanandiMalaysiaiaitu;(i) adakah terdapat hubungan signifikan antara aspek individu, struktur dan persekitaran perniagaan yang mempengaruhi kesedaran keusahawanan dalam kalangan pelajar ILJTM? (ii) adakah terdapat hubungan signifikan antara ciri-ciri keusahawanan dengan kesedaran keusahawanan dalam kalangan pelajar ILJTM? (iii) dan adakah cabaran keusahawanan yang dihadapi mempengaruhi kesedaran keusahawanan dalam kalangan pelajar ILJTM? Dalam mengupas persoalan di atas, Model Pembangunan Usahawan digunakan oleh pengkaji sebagai kerangka penelitian untuk membantu mendapatkan dan menjelaskan hasil dapatan kajian.

Di Malaysia, terdapat kajian yang dijalankan berkaitan keusahawanan seperti Idris (2009), kecenderungan keusahawanan dalam kalangan pelajar Institusi Pengajian Tinggi Awam (IPTA) dan Farhana (2013), keusahawanan dalam kalangan bakal graduan di Universiti Tun Husseion Onn Malaysia (UTHM). Namun begitu, masih belum terdapat sebarang kajian yang dijalankan berhubung dengan golongan pelajar di ILP. Oleh yang demikian, tujuan kajian ini dijalankan adalah untuk mengenalpasti hubungan pembolehubah bebas faktor, ciri-ciri dan cabaran yang dihadapi dengan kesedaran keusahawanan dalam kalangan pelajar ILP di Terengganu sebagai pembolehubah bersandar. Justeru hipotesis yang dicadangkan adalah:

H1a Terdapat hubungan yang signifikan antara aspek individu, struktur dan persekitaran

perniagaan dalam bidang keusahawanan dengan kesedaran keusahawanan dalam kalangan pelajar ILJTM.

H1b Terdapat hubungan yang signifikan antara ciri-ciri keusahawanan dengan kesedaran keusahawanan dalam kalangan pelajar ILJTM.

H1c Terdapat hubungan yang signifikan antara cabaran keusahawanan dengan kesedaran keusahawanan dalam kalangan pelajar ILJTM. 


\section{Kerangka kajian}

Kerangka kajian ini dihasilkan berlandaskan kepada Model Pembangunan Usahawan (Edward, 1991; Osman, 2007) dan hasil dapatan empirikal yang telah dijalankan oleh pengkaji terdahulu. Sehubungan itu, kerangka kajian ini melihat hubungan antara faktor, ciri-ciri dan cabaran yang dihadapi terhadap kesedaran keusahawanan sebagaimana yang ditunjukkan dalam Rajah 1. Pengujian hipotesis akan dilakukan terhadap semua item bagi melihat dan menentukan item yang paling dominan dalam mempengaruhi kesedaran keusahawanan sama ada elemen faktor, ciri-ciri mahupun cabaran keusahawanan.

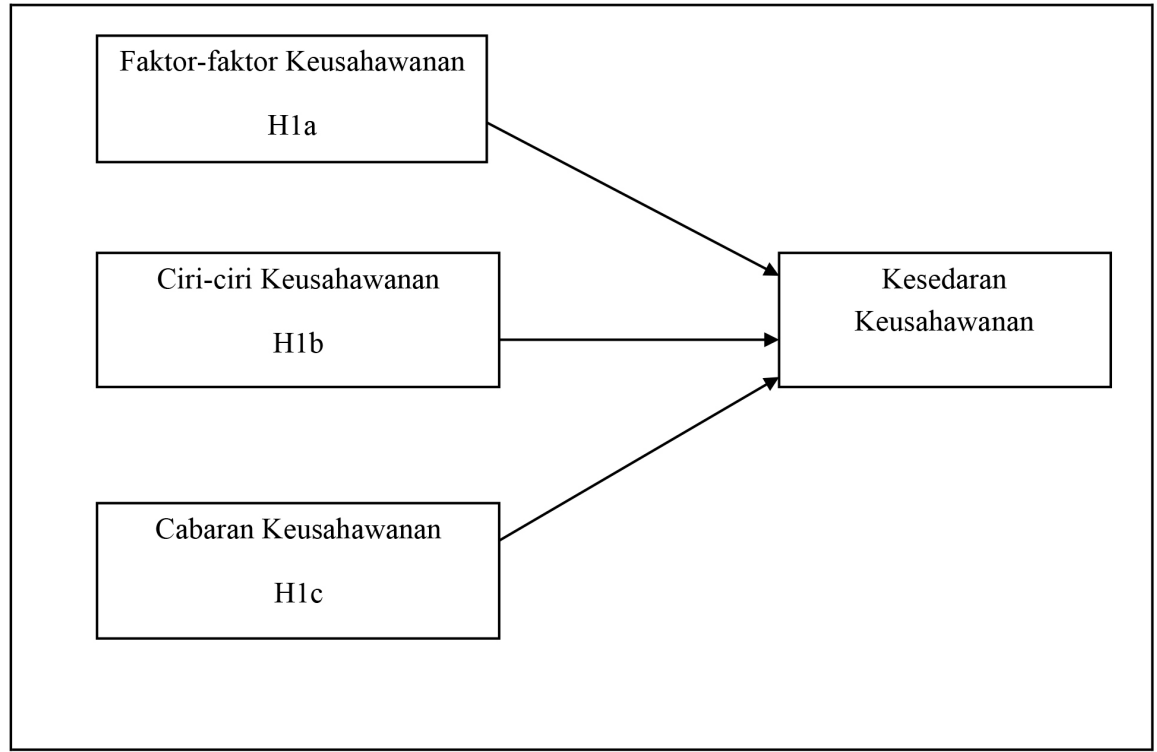

Rajah 1: Kerangka konsep kajian berdasarkan Model Pembangunan Usahawan Edward (1991)dan Osman (2007) terhadap kesedaran keusahawanan pelajar ILP di Terengganu

Secara operasional, faktor yang boleh mempengaruhi kesedaran keusahawanan dikategorikan sebagai faktor tertarik (pulling factor) dan faktor untuk mengukur kesedaran keusahawanan dalam konteks kajian ini dilihat daripada aspek individu, struktur dan persekitaran perniagaan. Faktor individu tertumpu kepada psikologi tingkah laku sosial manakala, kajian struktur melihat bagaimana budaya dan sokongan institusi dari segi sumber mempengaruhi pembentukan sifat keusahawanan (Noor dan Rahim, 2011; Martinelli, 1994). Persekitaran perniagaan pula melihat kepada struktur masyarakat individu usahawan dibesarkan.

Ciri-ciri usahawan seperti berkomitmen tinggi, berkemahiran mengurus, berdikari dan fleksibel berpotensi untuk berjaya dalam perkara yang dilakukannya (Hodgetts, 2011; Norbaizura, 2015). Melalui kajian ini, pengkaji ingin melihat sama ada ciriciri usahawan ini mempengaruhi tahap kesedaran keusahawanan dalam kalangan pelajar ILP. Malah, dari perspektif pengkaji, persediaan menghadapi cabaran dari aspek diri pelajar seperti kognitif, interpersonal, teknologi maklumat dan kepimpinanjuga adalah penting untuk mewujudkan kesedaran keusahawanan dalam diri pelajar (Izham et. al., 2012).

Kesedaran adalah berkait dengan tahap pengetahuan seseorang tentang sesuatu perkara dan tahap kesedaran pula melihat sejauhmana seseorang peka terhadap perubahan semasa sesuatu isu di samping 
memiliki minat terhadap sesuatu (Balwi et al., 2004). Dalam konteks kajian ini, kesedaran adalah berfokuskan kepada sikap ambil tahu golongan pelajar ILJTM terhadap perkara yang berlaku di sekeliling mereka dalam dunia keusahawanan dan kesedaran tentang minat mereka terhadap keusahawanan.

\section{Kaedah kajian}

Kajian ini adalah berdasarkan data yang dikutip daripada 280 orang responden terdiri daripada pelajar di Institusi Latihan Perindustrian Kuala Terengganu (ILPKT) dan Institut Latihan Perindustrian Marang (ILP Marang). Dalam konteks kajian ini, penentuan pemilihan lokasi kajian dibuat menggunakan teknik pensampelan di mana pengkaji memilih sampel kajian yang paling sesuai dan memenuhi keperluan tujuan kajian (Babbie, 2002). Kedua-dua lokasi kajian tersebut dipilih bersesuaian dengan fokus kajian yang ingin mengukur kesedaran keusahawanan dalam kalangan pelajar kemahiran ILP di Terengganu. Golongan pelajar tersebut merangkumi bidang atau pengkhususan berbeza yang sedang menuntut di ILPKT dan ILP Marang, Terengganu. Pengumpulan data dijalankan melalui tinjauan soal selidik yang dilakukan dalam bulan Mac 2019. Namun begitu, hanya 262 borang soal selidik yang dikembalikan semula oleh responden dan 250 set borang dipilih untuk dianalisis. Kadar maklum balas bagi kajian ini ialah 93.6\%. Satu set soal selidik yang mengandungi 5 bahagian telah digunakan untuk mengumpul maklumat daripada kumpulan sasaran.

Bahagian A adalah item-item berkaitan latar belakang demografi responden. Kajian ini merangkumi 49 item yang dibahagikan kepada bahagian B hingga E. Bahagian B sebanyak 13 item yang mengenalpasti respon pelajar mengenai faktor-faktor keusahawanan daripada aspek individu usahawan serta struktur dan persekitaran perniagaan. Bahagian $\mathrm{C}$ pula mempunyai sebanyak 9 item berkaitan ciri-ciri keusahawanan dan bahagian D sebanyak 17 item mengenai cabaran keusahawanan daripada beberapa sudut seperti sikap dan minat, kemahiran keusahawanan serta pendidikan dan pengetahuan keusahawanan sebagai pembolehubah tidak bersandar. Manakala bahagian E pula mengandungi 10 soalan mengenai kesedaran keusahawanan sebagai pembolehubah bersandar bagi kajian ini.

Pengukuran data dalam soal selidik ini adalah menggunakan skala Likert 5 peringkat $(1=$ sangat tidak setuju, 5 $=$ sangat setuju). Pembinaan instrumen kajian ini berdasarkan kepada kajian Hassan (2007), Ramlah dan Ab. Rahim (2009) serta Norasmah dan Salmah (2011). Semua item ini telah teruji dengan analisis kebolehpercayaan dan kesahihan instrumen yang meliputi pra uji dan kajian rintis menggunakan alfa Cronbach $(\alpha)$.Nilai alpha Cronbach yang signifkan adalah daripada 0.6 hingga 0.9. Maka, nilai alfa Cronbach .775 hingga .894 adalah boleh diterima. Soal selidik ini telah teruji penggunaan laras bahasanya melalui adaptasi soal selidik kajian oleh pengkaji terdahulu yang telah menjalankan kajian berkenaan keusahawanan.

\section{Dapatan kajian dan perbincangan}

\section{Hubungan Faktor, Ciri dan Cabaran dengan Kesedaran Keusahawanan Dalam Kalangan Pelajar Institut Latihan Perindustrian (ILP) di Terengganu}

Sungguhpun terdapat banyak faktor dan ciri-ciri serta cabaran dalam bidang keusahawanan, namun persoalan lebih penting yang diutarakan dalam kajian ini adalah yang manakah antara item tersebut yang berkait rapat dan paling mempengaruhi kesedaran keusahawanan dalam kalangan pelajar ILP di Terengganu. Dalam jadual 1, ujian korelasi Pearson 
sehala telah dijalankan bagi menguji sejauh mana hubungan antara kesemua faktor, ciri dan cabaran tersebut dengan kesedaran keusahawanan dalam kalangan pelajar ILP di Terengganu.

Berdasarkan analisis korelasi yang telah dijalankan seperti yang terdapat dalam jadual 1, di mana aras signifikan ialah $\mathrm{p}<0.01$, keputusan analisis tersebut menunjukkan korelasi yang paling tinggi ialah cabaran keusahawanan dengan kesedaran keusahawanan $(\mathrm{r}=.713, \mathrm{p}<0.01)$. Hal ini menunjukkan bahawa kebanyakan responden bersetuju cabaran yang harus dihadapi mempengaruhi kesedaran mereka dalam keusahawanan. Hasil ujian ini juga turut menunjukkan korelasi kedua tertinggi iaitu ciri-ciri keusahawanan dengan kesedaran keusahawanan $(\mathrm{r}=.582, \mathrm{p}<0.01)$. Manakala, faktor aspek individu usahawan serta struktur dan persekitaran perniagaan juga menunjukkan hubungan yang positif dengan kesedaran keusahawanan $(\mathrm{r}=.561, \mathrm{p}<0.01)$ yang mana keputusan ini menunjukkan bahawa rata-rata responden bersetuju bahawa faktor tersebut turut mempengaruhi kesedaran mereka dalam keusahawanan.

Jadual 1: Analisis Korelasi Pearson

\begin{tabular}{lcc}
\hline Pembolehubah & Person $(\mathrm{r})$ & Tahap signifikan $(\mathrm{p})$ \\
\hline $\begin{array}{l}\text { Faktor aspek individu serta } \\
\text { struktur dan persekitaran } \\
\text { perniagaan }\end{array}$ & $.561^{* *}$ & .000 \\
Ciri-ciri keusahawanan & $.582^{* *}$ & .000 \\
Cabaran keusahawanan & $.713^{* *}$ & .000 \\
\hline
\end{tabular}

**korelasi adalah signifikan pada 0.01 (2 tailed)

Kajian ini menunjukkan kesedaran keusahawanan melibatkan tiga item yang paling berpengaruh iaitu faktor, ciri-ciri dan cabaran keusahawanan. Sehubungan itu, pembentukan hipotesis dalam kajian ini adalah bagi menentukan hubungan antara ketiga-tiga item tersebut dengan kesedaran keusahawanan. Analisis regresi berganda dijalankan melalui perisian SPSS version 25 untuk melihat hubungan antara faktor aspek individu usahawan, struktur dan persekitaran perniagaan, ciri serta cabaran yang signifikan dengan kesedaran keusahawanan.
Nilai korelasi dalam Jadual 2 dan Jadual 3 bagi ketiga-tiga pemboleh ubah bebas (IV) dengan pembolehubah bersandar (DV) adalah tinggi $(\mathrm{R}=.751 \mathrm{a})$. Nilai adjusted $r$-square atau pekali nilai penentuan adalah 0.558 . Hal ini menunjukkan bahawa $55.8 \%$ varian dalam kesedaran keusahawanan dijelaskan oleh faktor aspek individu usahawan, struktur dan persekitaran perniagaan, ciri dan cabaran keusahawanan. Regresi kajian ini adalah signifikan dengan $\mathrm{F}=105.762, \mathrm{p}<0.05$.

Jadual 2: Ringkasan Model Analisis Regresi Berganda

\begin{tabular}{ccccc}
\hline Model & R & R Square & Adjusted R Square & Std. Error of the Estimate \\
\hline 1. & $.751 \mathrm{a}$ & .563 & .558 & 3.67871 \\
\hline
\end{tabular}

a. Predictors: Faktor, ciri, cabaran

b. Pembolehubah bersandar: Kesedaran keusahawanan 
LATIHAN PERINDUSTRIAN (ILP) JABATAN TENAGA MANUSIA DI TERENGGANU

Jadual 3: Kesignifikan Pembolehubah Bebas terhadap Kesedaran Keusahawanan

\begin{tabular}{lllllll}
\hline Model & & $\begin{array}{l}\text { Sum of } \\
\text { Squares }\end{array}$ & df & $\begin{array}{l}\text { Mean } \\
\text { Square }\end{array}$ & F & Sig. \\
\hline 1 & Regression & 4293.800 & 3 & 1431.267 & 105.762 & $.000 \mathrm{~b}$ \\
& Residual & 3329.100 & 246 & 13.533 & & \\
& Total & 7622.900 & 249 & & & \\
\hline
\end{tabular}

Ujian regresi berganda telah dijalankan bagi melihat terdapatnya hubungan antara item keusahawanan seperti faktor, ciri-ciri dan cabaran dengan kesedaran keusahawanan. Keputusan analisis regresi berganda ditunjukkan dalam Jadual 4 . Hasil dapatan membuktikan bahawa tiga pembolehubah bebas (IV) iaitu faktor aspek individu, struktur dan persekitaran perniagaan, ciri keusahawanan dan cabaran keusahawanan berkait secara positif dan signifikan dengan pembolehubah bersandar (DV), kesedaran keusahawanan.

Dapatan kajian menunjukkan pekali regresi bagi cabaran keusahawanan adalah paling tinggi iaitu .345. Dapatan ini menunjukkan bahawa pekali regresi terhadap sampel yang dipilih daripada populasi juga adalah positif, $\mathrm{t}=9.710$, $\mathrm{p}<0.05$. Seterusnya, nilai Beta juga menunjukkan bahawa pekali korelasi bagi item cabaran keusahawanan adalah paling tinggi sementara item faktor aspek individu, struktur dan persekitaran perniagaan adalah yang paling rendah.

Persamaan yang meramalkan Kesedaran Keusahawanan (KK) adalah seperti berikut:

$\mathrm{Y} 2:$ Konstan $+\mathrm{X} 1+\mathrm{X} 2+\mathrm{X} 3=\mathrm{X} 4$

$\mathrm{KK}=5.363+0.108+0.187+0.345=6.003$

Jadual 4: Analisis Regresi Berganda antara Item Keusahawanan dengan Kesedaran Keusahawanan

\begin{tabular}{|c|c|c|c|c|c|}
\hline \multirow[t]{2}{*}{ Model } & \multicolumn{2}{|c|}{$\begin{array}{l}\text { Unstandardized } \\
\text { Coefficients }\end{array}$} & \multirow{2}{*}{$\begin{array}{c}\begin{array}{c}\text { Standardized } \\
\text { Coefficients }\end{array} \\
\text { Beta }\end{array}$} & \multirow[t]{2}{*}{$\mathrm{t}$} & \multirow[t]{2}{*}{ Sig. } \\
\hline & $\mathrm{B}$ & $\begin{array}{l}\text { Std. } \\
\text { Error }\end{array}$ & & & \\
\hline 1 (Constant) & 5.363 & 1.896 & - & 2.829 & .005 \\
\hline $\begin{array}{l}\text { Faktor aspek individu, struktur } \\
\text { dan persekitaran perniagaan }\end{array}$ & .108 & .041 & .152 & 2.615 & .009 \\
\hline Ciri keusahawanan & .187 & .062 & .178 & 3.005 & .003 \\
\hline Cabaran keusahawanan & .345 & .036 & .525 & 9.710 & .000 \\
\hline
\end{tabular}

H1a Terdapat hubungan yang signifikan antara aspek individu, struktur dan persekitaran perniagaan dalam bidang keusahawanan dengan kesedaran keusahawanan dalam kalangan pelajar ILJTM.

Berdasarkan kepada analisis regresi bagi faktor aspek individu, struktur dan persekitaran perniagaan, dapatan kajian menunjukkan bahawa faktor tersebut mempunyai hubungan signifikan dan mempengaruhi kesedaran keusahawanan yang ditunjukkan oleh pekali beta 0.152 , $\mathrm{p}<0.05$, nilai $\mathrm{t}$ ialah 2.615 dan nilai signifikan 0.009. Maka, hipotesis H1a adalah diterima.

H1b Terdapat hubungan yang signifikan antara ciri-ciri keusahawanan dengan kesedaran keusahawanan dalam kalangan pelajar ILJTM. 
Hasil dapatan kajian menunjukkan bahawa pengaruh ciri-ciri keusahawanan juga mempunyai hubungan yang signifikan dengan kesedaran keusahawanan dengan nilai pekali beta $0.178, \mathrm{p}<0.05$ dan nilai $\mathrm{t}$ iaitu 3.005 dengan nilai signifikan 0.003. Lantaran itu, hipotesis H1b juga diterima.

H1c Terdapat hubungan yang signifikan antara cabaran keusahawanan dengan kesedaran keusahawanan dalam kalangan pelajar ILJTM.

Merujuk kepada analisis regresi berganda terhadap cabaran keusahawanan menunjukkan pengaruh yang paling tinggi terhadap kesedaran keusahawanan dengan pekali beta $0.525, \mathrm{p}<0.05$, nilai t iaitu 9.710 dan nilai signifikan 0.000 . Sehubungan itu, hipotesis bagi $\mathrm{H} 1 \mathrm{c}$ adalah diterima.

Maklum balas daripada responden dalam Jadual 4 memperlihatkan bahawa cabaran keusahawanan merupakan pembolehubah dominan yang mempengaruhi kesedaran keusahawanan berbanding item faktor dan ciri-ciri keusahawanan. Pekali regresi cabaran keusahawanan adalah paling tinggi iaitu .525. Dapatan ini menunjukkan bahawa pekali regresi terhadap sampel yang dipilih daripada populasi adalah positif, $t=9.710$, $\mathrm{p}<0.05$. Nilai Beta juga menunjukkan bahawa pekali korelasi bagi item cabaran keusahawanan adalah signifikan dan mempunyai hubungan positif serta dominan terhadap pembolehubah bersandar kesedaran keusahawanan.

Nilai R square dalam Jadual 2 menunjukkan pekali penentuan pembolehubah bebas kepada pembolehubah bersandar. Nilai R square .563 bermakna bahawa $56.3 \%$ pembolehubah bebas menunjukkan hubungan signifikan dan kolektif terhadap pembolehubah bersandar. Dalam analisis kuantitatif, penentuan pengaruh pembolehubah yang paling dominan adalah dengan melihat nilai Beta (Cresswell, 2008). Dalam hal ini, dapatan kajian mengikut maklum balas responden dalam Jadual 4 membuktikan cabaran keusahawanan mempunyai nilai terbesar, Beta $=.525$ pada aras .000. Ini bermakna pengaruh dominan mempengaruhi kesedaran keusahawanan dalam kalangan responden adalah cabaran yang dihadapi dalam bidang keusahawanan.

Penemuan penting kajian ini berpandukan hasil analisis mendapati ketiga-tiga pembolehubah bebas adalah signifikan hubungannya dengan kesedaran keusahawanan dalam kalangan pelajar ILP di Terengganu. Lazimnya, cabaran daripada segi sikap dan minat merujuk kepada seseorang yang sememangnya berkebolehan dan mempunyai kebarangkalian yang tinggi timbulnya kesedaran keusahawanan dalam diri mereka. Mereka berkebolehan untuk mengajar orang lain, mampu memimpin dan bekerja secara individu dan berpasukan. Individu yang tidak mempunyai sikap dan minat akan lebih sukar untuk menjadi seorang usahawan (Ramlah dan Ab. Rahim, 2009).Kebanyakan usahawan dipengaruhi oleh sikap positif yang dimiliki (Osman,2007). Misalnya, mereka berazam untuk merealisasikan idea sendiri, gemar mengetuai orang lain dan berdikari untuk menjana pendapatan.

Salah satu sikap yang boleh mendorong dan menjadi faktor kepada kesedaran keusahawanan adalah keinginan untuk berdikari (Thuaibah, 2007). Hal ini menjelaskan bahawa seseorang individu tersebut bebas membuat keputusan dan bertanggungjawab menentukan masa hadapan mereka sendiri. Manakala, cabaran daripada segi kemahiran keusahawanan serta pendidikan dan pengetahuan keusahawanan pula adalah saling berkait. Individu yang kurang mendapat pendidikan atau didedahkan dengan pengetahuan keusahawanan secara tidak langsung akan menghadapi masalah daripada segi kemahiran keusahawanan. Misalnya, kekurangan pengetahuan dalam pengurusan 
masa dan risiko akan menyebabkan seseorang individu kurang kemahiran berfikir secara kritis dalam membuat keputusan dan menyelesaikan masalah. Kesilapan atau lewat membuat keputusan boleh mendorong kepada kerugian untuk merebut peluang baharu atau kegagalan perniagaan (Norfadhilah \& Halimah, 2010).

Berdasarkan kajian terdahulu, timbulnya kesedaran keusahawanan adalah disebabkan atau dipengaruhi oleh kemahiran yang dimiliki berkaitan dengan bidang keusahawanan (Osman, 2007). Muhammad dan Khairul (2008), dalam kajiannya pula menjelaskan kemahiran keusahawanan mempunyai empat tahap. Salah satu tahap tersebut termasuklah mengenal pasti peluang perniagaan dan mampu merangka rancangan perniagaan. Begitu juga usahawan berupaya untuk membangunkan, meneliti dan merenggut peluang perniagaan serta pekerjaan. Kemahiran terakhir termasuklah keyakinan untuk mandiri iaitu bergerak atau bekerja sendiri. Manakala, pendidikan dan pengetahuan lazimnya berkait dengan pengurusan. Tamsilannya, untuk mengurus organisasi, perniagaan dan kewangan. Bardai (2000) dalam bukunya yang berjudul Keusahawanan dan Perniagaan juga telah menjelaskan hal yang sama. Wan Liz Ozman dan Sulzari (2002) dalam bukunya, Memperkasakan Usahawan pulamenyokong pentingnya individu mempunyai kesedaran keusahawanan sebelum mendapatkan pendidikan dan pengetahuan tentang dunia keusahawanan.

Hodgetts (2011) menyatakan ciri keusahawanan seperti individu yang mahir mengurus mampu memenuhi keperluan dalam memilih dan mengumpul pekerja yang cekap dan efisien untuk menjayakan sesuatu tugas serta mampu menguruskan sumber mereka dengan efektif dalam mencapai matlamat. Namun, pada masa yang sama, ciri dominan yang mempengaruhi kesedaran pelajar terhadap keusahawanan adalah fleksibel iaitu cepat bertindak dalam mengubah strategi serta yakin dan optimistik. Individu yakin terhadap diri sendiri dan tidak takut kepada kegagalan selain mempunyai motivasi untuk berjaya. Mereka sanggup menghadapi risiko dan tidak takut menghadapi kekuatan pesaing. Begitu juga dengan beberapa ciri keusahawanan lain yang berkait dengan kesedaran keusahawanan seperti pengambil risiko sederhana dan berdikari (Aziz, 2003).

Faktor dominan yang mempunyai hubungan signifikan dengan kesedaran keusahawanan adalah minat individu. Bertepatan dengan kajian Nasrul dan Halim (2015), dapatan kajian ini menunjukkan aspek individu usahawan seperti minat yang mendalam terhadap perniagaan menjadi salah satu faktor yang menimbulkan kesedaran individu tersebut terhadap keusahawanan. Hal ini disokong oleh Yuslina et al. (2011), kesusahan yang dilalui seseorang dalam kehidupannya boleh membentuk ciri-ciri peribadi keusahawanan, menanam minat dalam diri individu dan budaya pergaulan yang wujud sepanjang kesusahan yang ditempuh boleh menjadi pendorong kepada sifat keusahawanan (McClelland, 1961).

Seterusnya, melihat kepada struktur dan persekitaran perniagaan, seseorang yang tidak takut menghadapi kekuatan pesaing serta tahu bagaimana mengendalikan perniagaan menunjukkan kesedaran keusahawanan dalam diri individu tersebut adalah tinggi. (Yuslina et al., 2011). Kebanyakan usahawan mempunyai latar belakang keluarga yang terlibat dalam bidang perniagaan yang sama. Maka, tidak hairanlah mereka memperoleh ilmu perniagaan yang diajar dan diturunkan secara warisan keluarga. Keadaan ini boleh menimbulkan kesungguhan dalam diri usahawan untuk belajar. Secara tidak langsung,kesedaran keusahawanan yang timbul melalui pengetahuan dan kemahiran yang diperoleh membantu mereka memajukan diri dalam perniagaan (Norashidah et al., 2009). 
Justeru beberapa cadangan menerapkan bukan sahaja kesedaran tetapi juga kemahiran keusahawanan dalam kalangan pelajar kemahiran atau teknikal wajar diberi perhatian. Pertama, kerajaan boleh menjalankan program keusahawanan di ILP di seluruh Malaysia sepertimana Program Usahawan Siswazah yang dijalankan di IPTA yang mana siswazah diberi bimbingan dan khidmat nasihat mengenai perniagaan (Utusan Malaysia, April 2005). Kedua, juru cakap bagi Kementerian Pembangunan Usahawan Malaysia (KPUM) juga boleh mengadakan aktiviti jelajah (tour) di ILP untuk menarik minat golongan pelajar yang berkemahiran amali (hands-on) ini untuk mengikuti kursus keusahawanan. Pegawai yang telah lama berkhidmat semestinya lebih berpengalaman dan lebih bijak untuk menarik minat pelajar.

Ketiga, kerajaan dan pihak swasta boleh menubuhkan sebuah agensi khas atau Government Link Company (GLC) untuk mempromosikan dan memasarkan produk pelajar dengan lebih jauh. Misalnya, produk pelajar, Suis Pintar (Smart Switch) dan Kunci Keselamatan Pintu (Door Lock Security) yang menang dalam pertandingan reka cipta di Bangkok, Thailand pada 2 hingga 6 Februari 2019 yang lalu dan mempunyai nilai pasaran yang tinggi (Utusan Online, Februari 2019).

\section{Kesimpulan}

Oleh yang demikian, dapat disimpulkan bahawa faktor, ciri dan cabaran keusahawanan adalah saling berkait dalam mempengaruhi kesedaran keusahawanan seseorang. Faktor minat terhadap perniagaan terutamanya adalah sebab utama mengapa golongan pelajar cenderung untuk menjadi usahawan dan mereka lazimnya tidak takut untuk menghadapi persaingan. Begitu juga pelajar yang mahir mengurus, selayaknya sebagai seorang usahawan. Idris (2009) dalam kajiannya ke atas pelajar Sarjana Pentadbiran Perniagaan atauMaster of
Business Administration (MBA) di sebuah kolej yang terkemuka di Amerika Syarikat memperlihatkan bahawa kesedaran keusahawanan adalah lebih tinggi dalam kalangan pelajar yang mengambil kursus pengurusan tersebut. Namun, cabaran keusahawanan dari segi pengetahuan dan kemahiran sangat penting untuk diatasi agar minat dan potensi pelajar ini dapat dimanfaatkan dengan sepenuhnya ke arah pembangunan insan dan ekonomi Malaysia.

\section{Rujukan}

Ab. Aziz, Y. (2003). Prinsip keusahawanan. Petaling Jaya: Prentice Hall.

Audia, P. \& Rider, C.I. (2005). A garage and an idea: What more does an entrepreneur need? California Management Review, 48(1), 6-28.

Babbie, E. (2002). The Basic of Social Research. Belmont, CA: Wadsworth Publishing.

Balwi et al. (2004). Satu Kajian Terhadap Kesedaran dan Kesediaan Pelajar Universiti Menggunakan E-Pembelajaran Sebagai Alat Pembelajaran: Satu Kajian di Universiti Teknologi Malaysia, Skudai, Johor. Universiti teknologi Malaysia.

Bardai. B. (2000). Keusahawanan dan Perniagaan. Kuala Lumpur: Dewan Bahasa Dan Pustaka.

Chiew, T.M, Tam, Y.L \& Taha, M. (2011). Asas Keusahawanan. Penerbit Multimedia Sdn. Bhd.

Creswell, J. W. (2008). Education Research. Planing, Conducting and Evaluating Quantitative Research. Singapore: Pearson Merill Prentice Hall.

Delmar, F. (2000). The psychology of the entrepreneur. In $S$. Carter and D. Jones-Evans (eds.) Enterprise and small business: Principles, practice and policy. Harlow: Financial Times. 
Farhana, M. R. (2013). Pembudayaan Keusahawanan KeArah Mempengaruhi Kecenderungan Menceburi Bidang Keusahawanan Dalam Kalangan Bakal Graduan Di UTHM. Projek Sarjana, UTHM, Parit Raja: Universiti Tun Hussein Onn Malaysia.

Hisrich, R.D., Peters, M.P \& Shephard D.A. (2008). Entrepreneurship (International Edition). Singapore: The McGraw-Hill Education Asia.

Hodgetts, R.M. (2011). Contemporary Approach Towards Entrepreneur. California: Harcourt College Publishers.

Gartner, W. B., \& Bellamy, M. G. (2009). Creating the Enterprise (1st ed.). Canada: Thomson South-Western.

Idris, S. H. M. (2009). Kecenderungan Keusahawanan di Kalangan Pelajar Bidang Kejuruteraan di Institusi Pengajian Tinggi Awam di Kawasan Utara Semenanjung Malaysia. Projek Sarjana, UUM, Sintok: Universiti Utara Malaysia.

Ishak, Y., Khairunnisa, M. \& Zaimah, D. et al. (2011). Faktor Keusahawanan dan Prestasi Kejayaan Usahawan Melayu di Pulau Langkawi, Kedah. Prosiding Perkem VI, Jilid 2, 196-207.

Izham, M. H. \& Jamil, A. (2012). Perbandingan Keperluan Aspek Keusahawanan Dengan Lain-lain Aspek Kemahiran Generik dalam Memenuhi Pasaran Kerja Mengikut Persepsi Majikan dan Pelajar Institusi Pengajian Tinggi Swasta di Malaysia. Universiti Kebangsaan Malaysia.

Kementerian Pendidikan Tinggi. (2016). Pelan Tindakan Keusahawanan Institusi Pendidikan Tinggi 2016-2020. Dimuat turun daripada http://www. pnc.upm.edu.my/upload/dokumen/ menul320171013112713 Pelan_ Tindakan_Keusahawanan
IPT_20162020.pdf pada Oktober 12, 2018.

Kuratko, D.F. (2011). Entrepreneurship: A contemporary approach (5th ed.) California: Harcourt College Publishers.

Laporan Tahunan Bank Negara Malaysia. (2016). Pengangguran Belia di Malaysia: Perkembangan dan Pertimbangan Dasar. Dimuat turun daripada http://www.bnm.gov.my/files/ publication/ar/bm/2016/cp04_003_ rencana.pdf pada Oktober 12, 2018.

Martinelli, A. (1994). Entrepreneurship and management. in Smelser, N.J. and Swedberg, R. (Eds.) The Handbook of Economic Sociology. Princeton, N.J.: Princeton University Press.

McClelland, D. (1961). The Achieving Society. Princeton NJ: Van Nostrand.

Muhammad Haron, H. \& Khairul Anuar, A. (2008). Kemahiran Keusahawanan: Satu Kajian Analisis Kandungan Bukubuku Teks. Dimuat turun daripada http://eprints.uthm.edu.my/129/1/ muhammad_haron_husaini.pdf pada November $\overline{16}, 201 \overline{8}$.

Nasrul Hakim, M. \& Halim, J. (2015). Kajian Kecenderungan Keusahawanan Pelajar di Universiti Kuala Lumpur. Projek Sarjana, UUM, Sintok: Universiti Utara Malaysia.

Noor, N.M. \& A.Rahim, N. (2011). Kecenderungan Pelajar-pelajar Institut Kemahiran Mara (IKM) Johor Bahru Terhadap Bidang Keusahawanan. Fakulti Pendidikan, Universiti Teknologi Malaysia.

Norashidah, H., Norasmah, O. \& Noraishah, B. (2009). Konsep kesediaan keusahawanan berdasarkan kajian kes usahawan industri kecil dan sederhana (IKS) di Malaysia. Jurnal Pendidikan Malaysia, 34(1), 187-203. 
Norbaizura, M. I. (2015). Mengenalpasti Ciri-ciri Keusahawanan. Dimuat turun daripada https://www.scribd.com/ doc/272460798/Topik-2-MengenalPasti-Ciri-ciri-Keusahawanan-pdf pada Oktober 26, 2018.

Norfadhilah, N. \& Halimah, H. (2010). Aspirasi Kerjaya Keusahawanan dalam Kalangan Pelajar Institusi Pengajian Tinggi Awam. Jurnal Pendidikan Malaysia 35(1)(2010): 11-17.

Osman, M. H. (2007). Faktor-faktor Yang Telah Mendorong Graduan Alumni UTM Menceburi Bidang Keusahawanan. Universiti Teknologi Malaysia: Sarjana Muda.

Pendidikan Malaysia. (2017). Tahap Daya Saing Pelajar Institusi Pengajian Tinggi di Semenanjung Malaysia Dalam Pembangunan Keusahawanan. Dimuat turun daripada http://www. pendidikanmalaysia.com/2017/06/ pembangunan-keusahawananmalaysia.html pada Jun 15, 2019.

Thuaibah, A. (2007). Penglibatan Kaum Wanita Dalam Aktiviti Keusahawanan Di Negeri Johor: Kajian Terhadap Faktor-faktor Kritikal Kejayaan Dan Kegagalan Pengendalian Perniagaan. Jabatan Pembangunan Sumber Manusia Fakulti Pengurusan Dan Pembangunan Sumber Manusia. Universiti Teknologi Malaysia.
Utusan Online. 54,103 graduan masih menganggur. 18 Ogos 2017. Dimuat turun daripada http://www.utusan.com. my/berita/nasional/54-103-graduanmasih-menganggur-1.516175 pada November 12, 2018.

Utusan Online. Empat Pelajar Kolej Vokasional Juara Pertandingan Reka Cipta Antarabangsa. 11 Februari 2019. Dimuat turun daripada http:// www.utusan.com.my/pendidikan/ empat-pelajar-kolej-vokasionaljuara-pertandingan-reka-ciptaantarabangsa-1.838710 pada Mei 7, 2019.

Wan Liz Ozman, W. O. \& Sulzari, M. (2002). Memperkasakan Usahawan. Bangi: Utusan Publications \& Distributors Sdn Bhd.

Yuslina, S., Norhasyila, M. \& Suhaini, M. D. (2011). Faktor-faktor Yang Mempengaruhi Kejayaan Usahawan Kecil MARA di Negeri Perlis. Projek Sarjana: Politeknik Tuanku Syed Sirajuddin.

Zuraini, Z. (2000). Faktor-faktor yang mempengaruhi kemampuan usahawan Bumiputera di kawasan Sungai Petani, Kedah dalam memajukan perniagaan mereka. Projek Sarjana Muda, UTM, Skudai: Universiti Teknologi Malaysia. 